\title{
Effect of animal manure-based substrates on the emergence and vegetative growth of fodder oats (Avena sativa L.)
}

Efecto de sustratos a base de estiércol de animales sobre la emergencia y el crecimiento vegetativo de avena forrajera (Avena sativa L.)

Efeito dos substratos à base de esterco animal no aparecimento e crescimento vegetativo da aveia forrageira (Avena sativa L.)

Angel Canales Gutiérrez* (0)

Guadalupe Sucari Turpo 중 (1)
Universidad Nacional del Altiplano de Puno. Facultad de Ciencias Biológicas. Programa de Ecología. Puno. Perú.

Rev. Fac. Agron. (LUZ). 2022, 39(1): e223914

ISSN 2477-9407

DOI: https://doi.org/10.47280/RevFacAgron(LUZ).v39.n1.14

\section{Crop Production}

Associate editor: Professor Evelin Perez
Received: 21-09-2021

Accepted: 15-01-2022

Published: 10-02-2022

\section{Keywords:}

Cereal

Growth

Organic matter

\begin{abstract}
Oats (Avena sativa L.) are an annual forage grass of great current and potential importance in agricultural development. The objective was to determine the effect of animal manure-based substrates on the emergence and vegetative growth (stem height and leaf length) of forage oats (Avena sativa L.) in relation to organic amendments (chicken-cuy, cattle-sheep, llama-alpaca) over time. Growth variables were measured every ten days up to 60 days. A completely randomised experimental design was used; each treatment consisted of five replicates of ten seeds each. Analysis of variance (ANDEVA), Tukey's multiple comparison and regression and correlation analysis were performed. Both stem height and leaf length were higher when the seeds were established on a substrate based on a mixture of cattle and sheep manure and were lower with the llama-alpaca manure mixture. In general, growth expressed in stem height and leaf length increased over time. The application of organic matter of animal origin improves the quality of agricultural soils, which is reflected in plant growth and development.
\end{abstract}




\section{2-5 | Rev. Fac. Agron. (LUZ). 2022, 39(1): e223914. January - March. ISSN 2477-9407.}

\section{Resumen}

La avena (Avena sativa L.), es una gramínea forrajera anual de gran importancia actual y potencial en el desarrollo de la agricultura. El objetivo fue determinar el efecto de sustratos a base de estiércol de animales sobre la emergencia y el crecimiento vegetativo (altura del tallo y longitud de hojas) de la avena forrajera (Avena sativa L.) en relación con las enmiendas orgánicas (gallina-cuy, vacuno-ovino, llama-alpaca) en el tiempo, las variables de crecimiento se midieron cada diez días hasta los 60 días. Se utilizó un diseño experimental completamente aleatorizado; cada tratamiento constó de cinco repeticiones de diez semillas cada uno. Se realizaron análisis de varianza (ANDEVA), la comparación múltiple de Tukey y el análisis de regresión y correlación. Tanto la altura de tallo como la longitud de la hoja, fueron mayores cuando las semillas se establecieron en un sustrato a base de la mezcla estiércol de vacuno-ovino y fueron menores con la mezcla de estiércol llama-alpaca. En lineas generales, el crecimiento expresado en la altura del tallo y la longitud de la hoja se incrementó en el tiempo. La aplicación de materia orgánica de origen animal mejora la calidad de los suelos agrícolas, lo cual se refleja en el crecimiento y desarrollo de las plantas.

Palabras clave: cereal, crecimiento, materia orgánica.

\section{Resumo}

A aveia (Avena sativa L.) é uma erva forrageira anual de grande importância atual e potencial no desenvolvimento agrícola. $\mathrm{O}$ objetivo era determinar o efeito dos substratos à base de esterco animal no aparecimento e crescimento vegetativo (altura do caule e comprimento das folhas) da aveia forrageira (Avena sativa L.) em relação às emendas orgânicas (galinha-cuy, pecuária- ovelha, llama-alpaca) ao longo do tempo. As variáveis de crescimento foram medidas a cada dez dias até 60 dias. Foi utilizado um desenho experimental completamente aleatório; cada tratamento consistia de cinco réplicas de dez sementes cada. Análise de variância (ANDEVA), a comparação múltipla de Tukey e a análise de regressão e correlação foram realizadas. Tanto a altura do caule quanto o comprimento das folhas eram maiores quando as sementes eram estabelecidas em um substrato baseado em uma mistura de esterco bovino e ovino e eram mais baixas com a mistura de esterco de llama-alpaca. Em geral, o crescimento expresso na altura do caule e no comprimento da folha aumentou com o tempo. A aplicação de matéria orgânica de origem animal melhora a qualidade dos solos agrícolas, o que se reflete no crescimento e desenvolvimento das plantas.

Palavras-chave: cereais, crescimento, matéria orgânica.

\section{Introduction}

Oats (Avena sativa L.), is a monocotyledonous, annual herbaceous plant belonging to the Poaceae family (Suasaca et al., 2020), has a large number of varieties and are distributed in a wide diversity of altitudinal floors ranging from 2,500 to 4,000 meters above sea level. (Espinoza et al., 2018). It is undoubtedly a crop of wide climatic adaptation (Servin et al., 2018) and important as forage (Espinoza et al., 2018), as it has good nutritional and energy quality (Flores et al., 2016); it can be used from its growth stage (Espitia et al., 2012), in silage or hay (Condori et al., 2019) and for livestock feed (Rodríguez et al., 2020).
Among the forage species, oats, is widely cultivated in Peru (Mamani and Cotacallapa, 2018), despite the constant challenges it confronts (droughts and frosts) (Benique, 2019); in turn these occur with increasing intensity (Hijar et al., 2016) and therefore planting is done in the rainy season (December, January and February), where rainfall is recommended, being the harvest in March and April (Huallpa et al., 2016).

The use of animal manure in agriculture is very important (Ávalos de la Cruz et al., 2018), since it provides various nutrients that crops need for their development (Huerta et al., 2019) and increased production (Muñoz et al., 2016), and its use is of great social and environmental importance (Huerta et al., 2019). In the high Andes, there is evidence of loss of productive areas and an increase in degraded soils from 35 to 120 ha (Loza and Taype, 2021). Soil degradation has negative effects on plant yields; one of the factors is salinization, which influences the decrease in the biological fertility of the soil. The application of organic amendments increases enzymatic activity and soil respiration, reduces soil $\mathrm{pH}$ and electrical conductivity. The addition of organic fertilizer influences a higher rate of nitrogen mineralization and higher urease activity (Mogollón et al., 2011). Therefore, the incorporation of organic materials of animal or plant origin to soils has been shown to improve their physical, chemical and biological conditions, having effects on crop yield (Arrieche and Ruiz, 2014).

The objective was to determine the effect of animal manure-based substrates on the emergence and vegetative growth of forage oats (Avena sativa L.) in relation to organic amendments over time.

\section{Materials and Methods}

The study was conducted in the District of Asillo, Peru at 3,913 m.a.s.l. (coordinates $14^{\circ} 47^{\prime} 34^{\prime \prime} \mathrm{S} ; 7^{\circ} 21^{\prime} 22^{\prime \prime} \mathrm{W}$ ), with mean annual temperature of $16^{\circ} \mathrm{C}$ and monthly precipitation of $153 \mathrm{~mm}$ (Huallpa et al., 2016).

Two hundred seeds of Avena sativa L., selected on the basis of size and color, were sown in perforated trays, with ten seeds per replicate and five replicates per treatment. Irrigation was carried out every 2 days, with $250 \mathrm{~mL}$ of water for each treatment (table 1).

Table 1. Proportion of animal manure for each treatment.

\begin{tabular}{ccc}
\hline $\begin{array}{c}\text { Treatment } \\
\text { Control (T0) }\end{array}$ & $\begin{array}{c}\text { Substrate } \\
\text { Tierra agrícola }\end{array}$ & Ratio \\
\hline T1 & Agricultural land + chicken manure + guinea & 2:0.25:0.25. \\
& pig manure & \\
T2 & Agricultural land + cattle manure + sheep & $2: 0.25: 0.25$. \\
& manure & \\
T3 & Agricultural soil + llama manure + alpaca & $2: 0.25: 0.25$. \\
& manure & \\
\hline
\end{tabular}

Manures from chicken (Gallus gallus domesticus), bovine (Bos taurus), llama (Lama glama), sheep (Ovis orientalis), alpaca (Vicugna pacos) and cuy (Cavia porcellus), which were collected from the field (corral), then crushed and applied to the trays for each treatment, were evaluated.

The variables evaluated were:

Emergency percentage (E\%): the number of emerged seeds was determined by the following formula: 


\section{$\% \mathrm{E}=\frac{\text { Number of seedlingd emerged in the last count }}{\text { Number of seeds sown }}$}

Stem height: measurements were made on three individuals at random for each tray, using a tape measure.

Leaf length: measurements were made on three individuals at random for each tray, using a tape measure.

Leaf and stem growth was recorded during 60 days (December 2020 - February 2021). Observations were made from day 25, every five days from 09:00 to 11:00 h, randomly selecting three individuals per tray.

The experimental design used was a completely randomized design. An analysis of variance (ANDEVA) was performed, and Tukey's test of measures was used to determine the differences between treatments. Likewise, a regression analysis was performed to determine the relationship of the growth variables with respect to the evaluation time, and a correlation analysis was performed to determine the association between the variables studied. The statistical program INFOSTAT (2020), licensed for use, was used for all analyses.

\section{Results and discussion}

The percentage of emergence at 10 days was 76, 0, 14 and $50 \%$, for T0, T1, T2 and T3, respectively; while at 15 days the percentage of emergence was $100 \%$ for T0, T2 and T3; T 1 registered $26 \%$ and at 20 days it presented $100 \%$ of emergence, being the latest treatment. The time of seed emergence is reflected by the environmental conditions of the soil (Vargas, 1991) and the concentration of phytic acid in the seeds, due to the effect of fertilizers, which generates their vigor (Rivera et al., 2009).

Pino et al. (2008) indicated that in soils added with fresh poultry manure, mineralized $\mathrm{N}$ correlates more closely with uric acid content, which could be the cause of the lower percentage of emergence in $\mathrm{T} 1$. In contrast, $\mathrm{T} 0$ caused emergence in less time, and T2 and T3 treatments showed similar behavior.

As for the variables measuring vegetative growth, highly significant differences between treatments were recorded for stem height and leaf length $(\mathrm{p}<0.01)($ table 2$)$.

Table 2. Analysis of Variance (ANDEVA) for oat stem and leaf growth in different animal manure-based substrate mixtures.

\begin{tabular}{cccccc}
\hline \multicolumn{7}{c}{ Stem } \\
\hline S.V. & SS & DF & MS & F & $p$-valor \\
\hline Model & 704.18 & 3 & 234.73 & 8.09 & $<0.0001$ \\
Treatment & 704.18 & 3 & 234.73 & 8.09 & $<0.0001$ \\
Error & $12,585.36$ & 434 & 29 & & \\
Total & $13,289.54$ & 437 & & & \\
\hline \multicolumn{7}{c}{ Leaf } \\
Model & $1,420.21$ & 3 & 473.4 & 11.6 & $<0.0001$ \\
Treatment & $1,420.21$ & 3 & 473.4 & 11.6 & $<0.0001$ \\
Error & $17,718.5$ & 434 & 40.83 & & \\
Total & $19,138.7$ & 437 & & \\
\hline
\end{tabular}

Stem height was greater in T2 and T0 with averages of 11.75 and $10.03 \mathrm{~cm}$, respectively; while for T1 and T3 it was lower, with averages of 9.67 and $8.35 \mathrm{~cm}$, respectively (table 3 ).
Table 3. Stem height and leaf length in Avena sativa in mixtures of different organic substrates.

\begin{tabular}{ccc}
\hline Treatment & Stem height $(\mathrm{cm})$ & Leaf length $(\mathrm{cm})$ \\
\hline T0: control & $10.03 \mathrm{ab}$ & $18.55 \mathrm{~b}$ \\
T1: Chicken-cuy & $9.67 \mathrm{a}$ & $14.71 \mathrm{a}$ \\
T2: Bovine-sheep & $11.75 \mathrm{~b}$ & $18.72 \mathrm{~b}$ \\
T3: Llama-alpaca & $8.35 \mathrm{a}$ & $14.71 \mathrm{a}$ \\
\hline
\end{tabular}

Means with a common letter are not significantly different ( $\mathrm{p}$ $>0.05)$.

It has been established that plant development is influenced by the composition and type of soil (Castro et al., 2015).

The development of stems and leaves, is related to the use of various types of manure from domestic animals (Avalos de la Cruz et al., 2018), which possess the necessary macroelements such as $\mathrm{N}-\mathrm{P}_{2} \mathrm{O}_{5}-\mathrm{K}_{2} \mathrm{O}$ that are applied during sowing and in tillering (INIA, 2006), being an important aspect for agriculture (Avalos de la Cruz et al., 2018).

The effect of organic manure mixed with inorganic, influences the increase of nutrients for forage oats (Bar-Tal et al., 2004; Torres et al., 2016), this increase of nutrients influences the growth of all parts of the plant. The use of compost, as organic fertilizer, also influenced the increase of organic matter in the soil for the production of forage oats (Montaño et al., 2017), in the research conducted only animal manure was applied. There was a positive trend of increase in stem height and leaf length in all treatments in relation to time $(10,20,30,40,50$ and 60 days). Figure 1 shows the increase in stem height.

The regression coefficient for stem height at T0 was: $\mathrm{r}^{2}=0.88$; Y $=-6.87+0.40 \mathrm{X}$, while for leaf length $(\mathrm{cm})$ it was: $\mathrm{r}^{2}=0.63 ; \mathrm{Y}=1.79$ $+0.39 \mathrm{X}$. For T1 in stem height it was: $\mathrm{r}^{2}=0.90 ; \mathrm{Y}=-15.21+0.60 \mathrm{X}$.

The regression coefficient for $\mathrm{T} 2$ in stem height was: $\mathrm{r}^{2}=0.87$; $\mathrm{Y}$ $=-7.55+0.45 \mathrm{X}$, while for leaf length it was: $\mathrm{r}^{2}=0.61 ; \mathrm{Y}=1.34+$ $0.41 \mathrm{X}$. For T3 in stem height it was: $\mathrm{r}^{2}=0.78$; $\mathrm{Y}=-3.23+0.27 \mathrm{X}$.

As can be evidenced by the results of the regression analysis in all treatments, there was a significant response in terms of stem height and leaf length with respect to time.

Organic manures are important sources of organic carbon (Ren et al., 2014) together with the application of fertilizers substantially improve plant growth and yields (Mahmood et al., 2017; Torres et al., 2016), due to the increase of organic matter in the soil (Montaño et al., 2017), which plants require for their development (Huerta et al., 2019).

The values of Pearson's correlation coefficients ( $r$ ), between stem height and leaf length, showed a positive trend, which were determined by the effect of the different animal fertilizers $(\mathrm{T} 0=0.71$, $\mathrm{T} 1=0.91, \mathrm{~T} 2=0.78$ and $\mathrm{T} 3=0.63$ ) (figure 2 ) .

As can be seen in figure 2, there is a high correlation between stem height and leaf length which registered a high coefficient ( $\mathrm{r}=0.91)$ for $\mathrm{T} 1$, while for $\mathrm{T} 3(\mathrm{r}=0.63)$ it was lower. With the application of organic matter (animal manure) in soils, biological and physicochemical properties are improved (Cairo and Alvarez, 2017), allowing higher yield and plant productivity (Torres et al., 2016). Therefore, it has been determined that there is a leaf/stem ratio of $38 / 62$ until maturity in oats (INIA, 2008), and as it advances in its development the leaf area decreases (Pereira and Grabowski, 2015).

In the Peruvian altiplano, soils show evidence of increasing loss of productive areas (Muñoz et al., 2016). This soil degradation process has negative effects on crop yield. Therefore, by applying soil amendments, enzymatic activity increases, $\mathrm{pH}$ improves and there is a greater mineralization of nitrogen (Muñoz et al., 2016). 

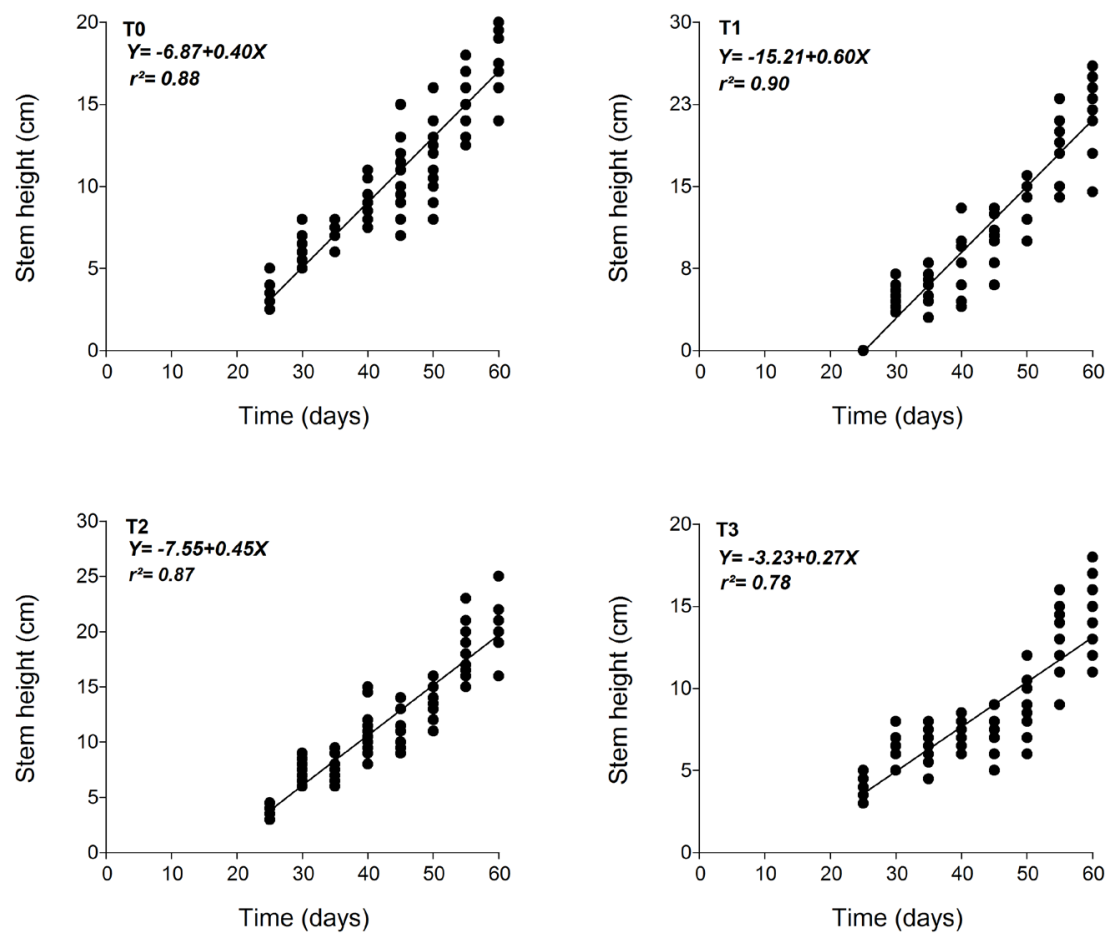

Figure 1. Stem growth $(\mathrm{cm})$ in different manure-based substrate mixtures $(\mathrm{T} 0=$ control, $\mathrm{T} 1=$ chicken-cuy, $\mathrm{T} 2=$ bovine-sheep and $\mathrm{T3}=$ plainalpaca) over time.
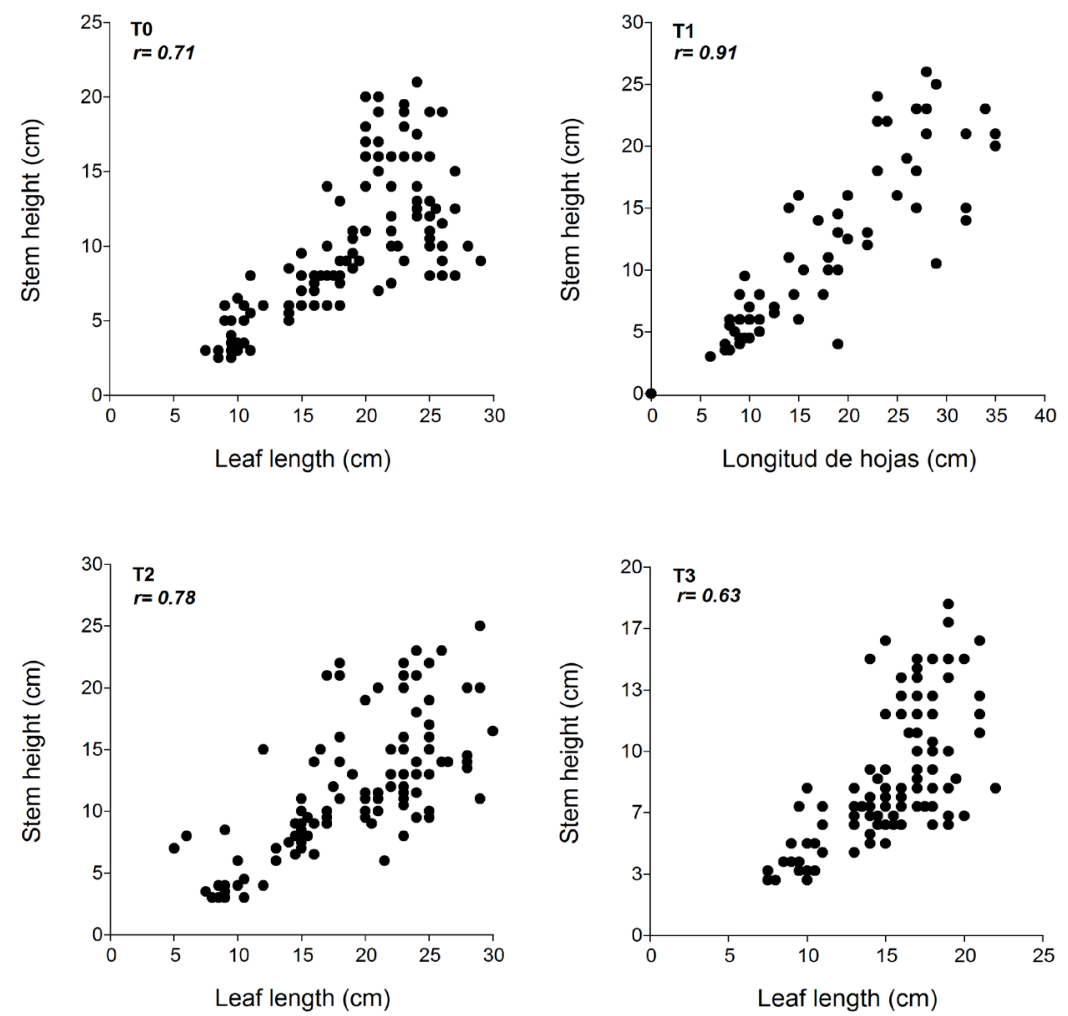

Figure2. Correlation between stem height $(\mathrm{cm})$ and leaf length $(\mathrm{cm})$ of Avena sativa, established in different manure-based substrate mixtures $(\mathrm{T} 0=$ control, $\mathrm{T} 1=$ chicken-cuy, $\mathrm{T} 2=$ bovine-sheep and $\mathrm{T} 3=$ llama-alpaca $)$. 


\section{Conclusions}

The bovine-sheep manure, llama-alpaca and the control reached a percentage of oat seed emergence of $100 \%$ in the shortest time (15 days), while with the chicken-cuy mixture it was 20 days. The shorter emergence time is important for obtaining and availability of oat plants, reducing the time of activities associated with propagation, optimizing the family economy.

Stem height and leaf length were greater when the seeds were established in a substrate based on a mixture of cattle and sheep manure, with the consequent increase in fresh and dry matter of the plants, and were lower with the llama-alpaca manure mixture.

In general terms, growth expressed in stem height and leaf length increased over time due to the effect of the different organic substrates used for oat germination, being an alternative to the use of inorganic fertilizers that favor soil degradation.

\section{Cited literature}

Arrieche, I. y Ruiz. M. (2014). Efecto de la fertilización orgánica con NPK sobre la materia orgánica, y el rendimiento del maíz en suelos degradados. Observador del Conocimiento, 2(1). https://bit.ly/3r7ViCQ

Ávalos de la Cruz, M., Figueroa,U., García,J., Vázquez,C., Gallegos,M. y Orona,I. (2018). Bioinoculantes y abonos orgánicos en la producción de maíz forrajero. Nova Scientia, 10(20): 170-189.https://bit.ly/3HSnsZy

Bar-Tal, A., Yermiyahu, U., Beraud, J., Keinan, M., Rosenberg, R., Zohar, D., Rosen, V. \& Fine, P. (2004). Nitrogen, phosphorus and potassium uptake by wheat and their distribution in soil following successive, annual compost applications. Journal of Environmental Quality, 33:18551865. https://bit.ly/3tet63T

Benique, E. (2019). Impacto del cambio climático en el rendimiento de la producción de cañihua (Chenopodium pallidicaule) en la Región Puno. Revista de Investigaciones Altoandinas, 21(2): 100-110. https:// bit.ly/3r1P0oh

Cairo, P. y Âlvarez,U. (2017). Efecto del estiércol en el suelo y en el cultivo de la soya Glycine max (L.) Merr. Pastos y Forrajes, 40(1): 37-42. Recuperado en 02 de diciembre de 2021. https://bit.ly/339UAwS

Castro, L., Murillo, M., Uribe, L. y Mata, R. (2015). Inoculación al suelo con Pseudomonas fluorescens, Azospirillum oryzae, Bacillus subtilis y microorganismos de montaña $(\mathrm{mm})$ y su efecto sobre un sistema de rotación soya-tomate bajo condiciones de invernadero. Agronomía Costarricense, 39(3): 21-36. https://bit.ly/3GgxK55

Condori, R., Loza, G., Achu,C. y Alberto, H. (2019). Calidad del ensilaje de avena forrajera (Avena sativa L.) conservado en tres diferentes tipos de silos artesanales. JSAAS, 6(2): 57-65. https://bit.ly/3ndKkuu

Espinoza, F., Nuñez,W., Ortiz, I. y Choque, D. (2018). Producción de forraje y competencia interespecífica del cultivo asociado de avena (Avena sativa) con vicia (Vicia sativa) en condiciones de secano y gran altitud. Revista de Investigaciones Veterinarias del Perú, 29(4): 1237-1248. https://bit.ly/3qd0u9u

Espitia, E., Villaseñor, H., Tovar, R., Olan, M. y Limon, A. (2012). Momento óptimo de corte para rendimiento y calidad de variedades de avena forrajera. Revista Mexicana de Ciencias Agrícolas. Revista Mexicana de Ciencias Agrícolas, 3(4): 771-783. https://bit.ly/3f7aHO7

Flores, M., Sánchez, R., Echavarría, F., Gutiérrez, R., Rosales,C. y Salinas, H. (2016). Producción y calidad de forraje en mezclas de veza común con cebada, avena y triticale en cuatro etapas fenológicas. Revista Mexicana de Ciencias Pecuarias, 7(3): 275-291. https://bit.ly/3zLF9qx

Hijar, G., Bonilla, C., Munayco, C., Gutierrez, E. y Ramos,W. (2016). Fenómeno el niño y desastres naturales: intervenciones en salud pública para la preparación y respuesta. Revista Peruana de Medicina Experimental y Salud Pública, 33(2): 300-310. https://bit.ly/3FectHO

Huallpa, R., Céspedes, R. y Esprella, B. (2016). Evaluación del efecto de biol bovino en la producción y calidad de la avena forrajera (Avena sativa L.), en época de invierno en la estación experimental Choquenaira, Viacha - La Paz. Revista de Investigación e Innovación Agropecuaria y de Recursos Naturales, 3(3): 103-113. https://bit.ly/3JTrClL
Huerta, E., Cruz, J. y Aguirre, L. (2019). La apreciación de abonos orgánicos para la gestión local comunitaria de estiércoles en los traspatios. Revista de Alimentación Contemporánea y Desarrollo Regional, 29(53): 1-24. https://bit.ly/3Gqoco4

INFOSTAT. (2020). Sofware estadistico. Versión 2020 con licencia de uso.

Instituto Nacional de Innovación Agraria (INIA). (2006). Avena INIA $902-$ Africana. Instituto Nacional de Innovación Agraria (INIA). Programa Nacional de Investigación en pastos forrajes estación experimental agraria Illpa. Puno. 4 pp.

Instituto Nacional de Innovación Agraria (INIA). (2008). Avena Forrajera Inia 905 - La Cajamarquina. Plegable No 7, Instituto Nacional de Innovación Agraria (INIA). Hecho el Depósito Legal en la Biblioteca Nacional del Perú $N^{\circ}$ : 2008-14042. Distrito Baños del Inca. Cajarmarca. 4 pp.

Loza, A. y Taype, I. (2021). Análisis multitemporal de asociaciones vegetales y cambios de uso del suelo en una localidad altoandina, Puno-Perú. Uniciencia, 35(2): 1-19. https://bit.ly/3faKpuA

Mamani, J. y Cotacallapa, F. (2018). Rendimiento y calidad nutricional de avena forrajera en la región de Puno. Revista de Investigaciones Altoandinas, 20(4): 385-400. https://bit.ly/3qbUgGM

Mahmood, F., Khan, I., Ashraf, U., Shahzad, T., Hussain, S., Shahid, M., Abid, M. y Ullah, S. (2017). Effects of organic and inorganic manures on maize and their residual impact on soil physico-chemical properties. Journal of Soil Science and Plant Nutrition, 17(1): 22-32. https://bit. ly/3GK0ovy

Mogollón, J., Tremont, O. y Rodríguez, N. (2011). Efecto del uso de un vermicompost sobre las propiedades biológicas y químicas de suelos degradados por sales. Venesuelos, 9 (1 y 2):48-57.https://bit.ly/3f9AWnh

Montaño, M., Hernández, A., Martínez, A., Ojeda, D., Núñez, A. y Guerrero, V. (2017). Producción y contenido nutrimental en avena forrajera fertilizada con fuentes químicas y orgánicas. Revista Fitotecnia Mexicana, 40(3): 317 - 32.https://bit.ly/3qbVr9a

Muñoz, J., Huerta, M., Lara, A., Rangel, R., y De la Rosa, J. (2016). Producción y calidad nutrimental de forrajes en condiciones del trópico húmedo de México. Revista Mexicana de Ciencias Agrícolas, 16: 3329-3341. https://bit.ly/3fboqUq

Pereira, K. y Grabowski, C. (2015). Potencial de la escoria siderúrgica en la inducción de resistencia a enfermedades foliares del trigo (Triticum aestivum L.). Investigación Agraria. 17(2): 98-107. https://bit. $1 \mathrm{y} / 3 \mathrm{~A} 2 \mathrm{BtB} 2$

Pino, A., Repetto, C. y Mori, C. (2008). Patrones de descomposición de estiércoles en el suelo. Revista Terra Latinoamericana, 26(1): 43-52. https://bit.ly/3tiQhKr

Ren, T., Wang, J., Chen, Q., Zhang, F. \& Lu, S. (2014). The effects of manure and nitrogen fertilizer applications on soil organic carbon and nitrogen in a high input cropping systems. PLoS ONE. 9(5): e97732. https://bit. ly/3HQtCcC

Rivera, J., Peraza, F., Serratos, J., Posos, P., Guzmán, S., Cortez, E., Castañón, G. y Mendoza, M. (2009). Efecto de la fertilización nitrogenada y fosforada en el contenido de ácido fítico y vigor de la semilla de avena de la variedad Saia en México. Revista Internacional de Botánica Experimental, 78: 37-42. https://bit.ly/3JV7Xlb

Rodríguez, S., Salgado, O., García, G., Cervantes, F., Figueroa, M. \& Mendoza, M. (2020). Chemical and organic fertilization in oats: seed yield and quality. Agronomía Mesoamericana, 31(3): 567-579. https://bit. ly/3f73ldA

Servin, M., Sánchez, R., Ramírez, O., Galindo, M. y Gutiérrez, H. (2018). Modelos para programación y optimización de agua de riego en avena forrajera. Revista Mexicana de Ciencias Pecuarias, 9(4): 668-684. https://bit.ly/3qarpCL

Suasaca, L., Apaza, A., Flores, J., Perca, O. y Quinto,W. (2020). Influencia de las pacas de avena en la temperatura y humedad en las viviendas en zonas altoandinas. Investigación \& Desarrollo, 20(1): 215-227. https:// bit.ly/3zJOBe3

Torres, E., Ariza, D., Baena, C., Cortés, S., Becerra, L. y Riaño. C. (2016). Efecto de la fertilización en el crecimiento y desarrollo del cultivo de la avena (Avena sativa). Pastos y Forrajes, 39(2): 102-110. Recuperado en 02 de diciembre de 2021, de https://bit.ly/3r7EEmO

Vargas, M. (1991). Factores que afectan la germinación de semillas. Boletín Técnico, 24(1): 26-31. https://bit.ly/3JXF8V9 